\title{
Keanekaragaman dan Kemerataan Spesies Anggota Ordo Anura di Lereng Selatan Gunung Merapi Tahun 2012
}

\author{
Donan Satria Yudha1), Yonathan'2), Rury Eprilurahman", \\ Septiana Indriawan ${ }^{2}$, Eka Cahyaningrum ${ }^{2)}$ \\ 1)Laboratorium Sistematika Hewan, Fakultas Biologi Universitas Gadjah Mada \\ ${ }^{2)}$ Kelompok Studi Herpetologi, Fakultas Biologi Universitas Gadjah Mada \\ Email: yonathan8421@mail.ugm.ac.id
}

\begin{abstract}
Merapi volcano as one of national park is an ecotourism site which is very potential to visit. Information about species diversity for a national park is very important especially if its area fluctuated susceptibly. Two years after 2010 Merapi eruption, there are no research about species diversity and evenness of Anuran in that place. The research is carried out during June-November 2012 which is dry season. The objective of this research is to study the species diversity and evenness of Anuran in southern slope of Mount Merapi. The research is carried out in 6 locations; those are Kali Kuning, Telogo Muncar, Telogo Nirmolo, Petak Pitu, Bukit Turgo, and Bukit Plawangan. We used Visual Encounter Survey (VES) method combined with transect in Kali Kuning, Telogo Muncar, and Petak Pitu. VES method combined with time search in Telogo Nirmolo and Bukit Turgo. VES method combined with track exploration in Bukit Plawangan. Species diversity is analyzed with Shanon-Wiener diversity index. Species evenness is analyzed with Pielou evenness index. Total individuals each species is counted to know species abundance. Species diversity of anuran in southern slope of Mount Merapi is consisted of 12 species' which is distributed in 6 locations. The highest diversity and evenness of anuran is at Bukit Turgo $\left(H^{\prime}=1.31\right.$; $\mathrm{E}=0.94)$. The lowest diversity and evenness of anuran is at Petak Pitu $\left(H^{\prime}=0.49 ; E=0.3\right)$. Species diversity of anuran in southern slope of Mount Merapi is low (Bukit Turgo and Kali Kuning) and very low (Bukit Plawangan, Telogo Muncar, Telogo Nirmolo, and Petak Pitu). Species evenness of anuran in southern slope of Mount Merapi is stable (Telogo Nirmolo and Bukit Turgo), still labil (Bukit Plawangan, Kali Kuning, and Telogo Muncar), and oppressed (Petak Pitu).
\end{abstract}

Keywords: Diversity, Evenness, Anuran, Merapi, Dry Season

\section{Abstrak}

Gunung Merapi sebagai salah satu taman nasional, merupakan daerah ekowisata yang sangat potensial untuk dikunjungi. Data keanekaragaman jenis bagi suatu taman nasional merupakan hal yang sangat penting terutama bila rentan terjadi fluktuasi. Dua tahun setelah erupsi Merapi tahun 2010, belum ada penelitian mengenai keanekaragaman dan kemerataan spesies anggota Ordo Anura di tempat tersebut. Penelitian dilakukan pada Bulan Juni-November 2012 yang merupakan musim kemarau. Tujuan dari penelitian ini adalah untuk mempelajari keanekaragaman dan kemerataan spesies anggota Ordo Anura di lereng selatan Gunung Merapi selama Bulan Juni-November 2012. Penelitian dilakukan di 6 lokasi yaitu Kali Kuning, Telogo Muncar, Telogo Nirmolo, Petak Pitu, Bukit Turgo, dan Bukit Plawangan. Metode yang digunakan adalah Visual Encounter Survey (VES) dengan transek pada Kali kuning, Telogo Muncar, dan Petak Pitu. Metode VES dengan time search pada Telogo Nirmolo dan Bukit Turgo. Metode VES dengan jelajah pada Bukit Plawangan. Keanekaragaman dianalisis dengan indeks keanekaragaman Shanon-Wiener. Kemerataan jenis dianalisis dengan indeks kemerataan Pielou. Cacah individu tiap spesies dihitung untuk mengetahui kemelimpahan spesies. Keanekaragaman jenis anura di lereng selatan Gunung Merapi terdiri dari 12 spesies yang tersebar di 6 lokasi. Keanekaragaman dan kemerataan spesies anura tertinggi yaitu pada Bukit Turgo $\left(H^{\prime}=1,31 ; E=0,94\right)$. Keanekaragaman dan kemerataan spesies anura terendah yaitu pada Petak $\mathrm{Pitu}\left(\mathrm{H}^{\prime}=0,49 ; \mathrm{E}=0,3\right)$. Keanekaragaman spesies anura di lereng selatan Gunung Merapi masih tergolong rendah (Bukit Turgo dan Kali Kuning) dan sangat rendah (Bukit Plawangan, Telogo Muncar, Telogo Nirmolo, dan Petak Pitu). Kemerataan spesies anura di lereng selatan Gunung Merapi ada yang sudah stabil (Telogo Nirmolo dan Bukit Turgo), masih labil (Bukit Plawangan, Kali Kuning, dan Telogo Muncar), dan ada pula yang tertekan (Petak Pitu).

Kata Kunci: Keanekaragaman, Kemerataan, Anura, Merapi, Musim Kemarau 


\section{Pendahuluan}

Gunung Merapi merupakan salah satu gunung api paling aktif yang ada di Indonesia. Gunung Merapi terletak di antara dua provinsi yaitu Provinsi Jawa Tengah dan Provinsi D.I. Yogyakarta. Sebagai daerah ekowisata di Sleman, taman nasional ini memiliki jumlah pengunjung yang tinggi yang menjadi-kannya potensi daerah yang edukatif. Sebagai taman nasional, data dan informasi mengenai keanekaragaman fauna di tempat tersebut sangatlah penting.

Pada Oktober-November 2010, Merapi mengalami erupsi dan dapat diklasifikasikan sebagai erupsi terbesar sejak 1872. Erupsi pada tahun 2010 telah merusak ekosistem dari Gunung Merapi. Aliran awan panas telah menghancurkan hutan dan ekosistem yang lain dengan total sekitar 2400 ha (Andayani, 2011). Kerusakan terparah dialami oleh lereng selatan karena aliran lahar dominan mengarah ke sisi selatan. Erupsi terakhir telah membuat celah lahar terbuka ke arah selatan sehingga diduga pada erupsi berikutnya aliran lahar akan mengarah ke sisi selatan. Keadaan ini tentu saja akan mengubah komposisi spesies di tempat tersebut.

Lereng selatan Gunung Merapi merupakan habitat yang potensial untuk berbagai spesies amfibi khususnya anggota Ordo Anura. Anura merupakan suatu kelompok hewan yang memiliki ciri-ciri berkaki empat (tetrapoda), pentadac-tylus, tidak dapat mengontrol suhu tubuhnya (poikiloterm/ectoterm), kulitnya licin dan lembab, serta memiliki dua fase kehidupan yaitu fase larva di akuatik, dan fase dewasa di darat. Selain itu, amfibi umumnya bereproduksi secara ovipar meskipun ada juga beberapa yang bereproduksi dengan ovovivipar. Amfibi yang terdiri dari katak dan kodok telah lama digunakan sebagai indikator lingkungan karena peran pentingnya di dalam ekosistem (Howell, 2002). Anura memiliki persebaran yang luas, yaitu dari laut hingga pegunungan yang tinggi (Kurniati, 2003). Apabila terdapat gangguan pada habitatnya, maka keane-karagaman dan kemerataannya di alam pun akan berubah karena tidak semua Anura mampu beradaptasi dengan baik. Hal yang sama juga berlaku terhadap keanekaragaman dan kemerataan Ordo Anura di lereng selatan Gunung Merapi.

Setelah dua tahun terjadinya erupsi Merapi, belum ada penelitian mengenai keanekaragaman dan kemerataan spesies khususnya anggota Ordo Anura di tempat tersebut. Hal ini menjadi sangat penting karena dapat menjadi penelitian mengenai waktu suksesi Ordo Anura di lokasi tersebut apakah dua tahun sudah cukup untuk mengembalikan keadaan habitat mereka seperti semula atau belum. Waktu penelitian ini pun bertepatan dengan musim kemarau yaitu berkisar dari Bulan Juni hingga November. Hal ini dapat menjadi poin tersendiri untuk melihat keanekaragaman dan kemerataan Ordo Anura apabila berlangsung di musim kemarau. Diharap-kan akan ada penelitian lanjutan yang serupa namun dilakukan di musim penghujan untuk melihat perbedaannya. Perbedaan musim tersebut diduga akan memberikan pengaruh secara signifikan.

Perubahan kualitas lingkungan harus dikaji untuk mempelajari seberapa banyak spesies atau keanekaragamannya yang ada di wilayah lereng selatan Gunung Merapi. Selain itu, diperlukan pula penelitian mengenai kemerataan spesies dimana dapat diketahui apakah ada spesies yang mendominasi di lokasi kajian tersebut atau tidak. Data yang diperoleh akan sangat penting karena penelitian ini akan menghasilkan data kuantitatif keanekaragaman dan kemerataan Ordo Anura. Selain itu data tersebut akan menjadi acuan untuk setiap penelitian mengenai keanekaragaman spesies anggota Ordo Anura di lereng selatan Gunung Merapi pada masa yang akan datang.

Setelah terjadinya erupsi Merapi tahun 2010, belum ada penelitian mengenai keanekaragaman dan ke- merataan spesies anggota Ordo Anura. Hal ini sangat disayangkan mengingat pentingnya penelitian mengenai waktu suksesi Ordo Anura tersebut setelah terjadinya erupsi Merapi. Dua tahun dirasa adalah waktu yang 
ideal untuk melihat komposisi spesies di lereng selatan Gunung Merapi. Dipilihnya Bulan Juni hingga November ini untuk melihat keanekaragaman dan kemerataan yang ada di lapangan selama 6 bulan terakhir dalam satu tahun. Enam bulan terakhir tersebut merupakan musim kemarau. Hasil yang didapat ini merupakan data keanekaragaman dan kemerataan pada musim kemarau sehingga masih perlu dilakukan penelitian serupa pada musim hujan sebagai data pembanding sekaligus pelengkap di lereng selatan Gunung Merapi ini.

Tujuan penelitian untuk mempelajari keanekaragaman dan kemerataan spesies anggota Ordo Anura di lereng selatan Gunung Merapi selama Bulan JuniNovember tahun 2012. Selain itu, penelitian ini juga bertujuan untuk mengetahui spesies apa yang paling melimpah di tiap lokasi.

\section{Materi dan Metode}

Penelitian dilakukan selama 6 bulan yaitu dari Bulan Juni-November 2012. Penelitian dilakukan di enam lokasi yaitu di Bukit Turgo, Petak Pitu, Bukit Plawangan, Telaga Muncar, Telaga Nirmolo, dan Kali Kuning.

1) Telaga Muncar terletak pada ketinggian + 839 meter di atas permukaan laut. Pada wilayah ini, terdapat hutan yang telah dijamah oleh manusia. Habitathabitat yang dapat ditemukan adalah kolam, dan air terjun. Vegetasi di sekitas air terjun adalah hutan yang terdiri dari pepohonan dan semak. Lantai hutan tertutupi oleh serasah.

2) Bukit Plawangan terletak pada ketinggian \pm 993-1310 meter di atas permukaan laut. Stasiun ini memiliki medan yang curam dengan vegetasi pepohonan yang rapat.

3) Bukit Turgo terletak pada ketinggian + 900-1000 meter di atas permukaan laut. Stasiun ini memiliki medan yang curam, namun pada beberapa bagian, terdapat jalur pendakian. Vegetasi pada stasiun ini juga didominasi oleh pepohonan yang rapat.

4) Kali Kuning terletak pada ketinggian \pm 926 meter di atas permukaan laut. Stasiun ini memiliki jarak yang relatif dekat dengan Bendungan Plunyon. Terdapat sungai dengan lebar 7-8 meter ketika musim penghujan dan kurang dari 2 meter ketika musim kemarau. Vegetasi riparian sekitar sungai didominasi oleh serasah dan substrat berbatu. Aliran air pada sungai cenderung lambat pada tepi sungai, dan deras pada bagian tengah sungai.

5) Telaga Nirmolo terletak pada ketinggian + 889 meter di atas permukaan laut. Stasiun ini memiliki kolam dan beberapa tempat yang berfungsi sebagai area penampung air namun tidak terdapat sumber air pada saat dilakukan sampling. Vegetasi yang dominan pada daerah ini adalah pohon cemara dan rerumputan.

6) Petak Pitu terletak pada ketinggian \pm 825 meter di atas permukaan laut. Stasiun ini memiliki sungai yang berbatu-batu, namun sungai ini tidak dilewati oleh aliran materi vulkanik dari Gunung Merapi. Vegetasi pada daerah ini meliputi : bambu, pohon cemara, semak, dan rerumputan.

Metode sampling yang digunakan adalah Visual Encountered Survey (VES) yang dipadukan dengan metode time search, metode jelajah, dan metode transek. Metode-metode ini digunakan berdasarkan Heyer et al. (1994) dan Kusrini (2009). Sampling yang dilakukan di stasiun pengamatan Kali Kuning, Telogo Muncar, dan Petak Pitu akan menggunakan metode VES yang dipadukan dengan transek.

Pada stasiun pengamatan Kali Kuning, transek yang digunakan se- panjang 1000 meter. Pada stasiun pengamatan Telogo Muncar, transek yang digunakan dimodifikasi dengan area lahan berbentuk setengah lingkaran dengan jarak 250 meter. Pada stasiun pengamatan Petak Pitu, transek yang digunakan sepanjang 340 meter. Pada stasiun pengamatan Bukit Plawangan, digunakan metode VES dengan metode jelajah dengan jarak sekitar 1000 meter hingga puncak Bukit Plawangan. Pada stasiun pengamatan Bukit Turgo dan Telogo Nirmolo menggunakan VES dengan time search selama 1,5 jam. Di Bukit Turgo, sampling dilakukan di 3 substasiun yaitu di Siraman Lanang, Siraman Candi, dan Siraman Wedok. Pemakaian metode transek dikarenakan terdapat gradient 
lingkungan yang bervariasi sehingga transek cocok untuk digunakan dalam pencarian Anura. Sampling dilakukan dalam 2 waktu aktif herpetofauna, yaitu nokturnal dan diurnal. Menurut Eprilurahman dan Kusuma (2011), amfibi umumnya aktif pada pukul 08.00-14.00 (untuk waktu diurnal) dan pukul 19.00-23.00 (untuk waktu noc- turnal). Spesimen yang didapat akan di- identifikasi menggunakan beberapa referensi, yaitu Iskandar (1998), Kurniati (2003), dan Iskandar \& Colijn (2001).

Setiap cacah individu dari spesies anggota Ordo Anura akan direkam semua datanya meliputi SVL dan berat. Data yang diperoleh kemudian dianalisis menggunakan indeks keanekaragaman Shanon-Wiener untuk mendapat nilai keanekaragaman spesies secara kuantitatif. Indeks Kemerataan Pielou juga digunakan untuk analisis kemerataan dari spesies di wilayah tersebut.

1. Indeks Diversitas Shanon-Weiner (Shannon in Odum, 1971)

$\mathrm{H}=-\sum$ pi In pi

$\mathrm{H}$ : Indeks Diversitas Shanon-Weiner

$\mathrm{Pi}: \mathrm{ni} / \mathrm{N}$ (ni: Total individu per spesies -i, $\operatorname{dan} \mathrm{N}$ : total seluruh individu).

Menurut Brower \& Zarr (1997), keanekaragaman dikatakan rendah apabila nilai $\mathrm{H}<1$, jika nilainya berkisar antara 1-1,5 maka dikatakan rendah dan dikatakan sedang jika nilainya berkisar antara 1,5-2,0. Sedangkan dikatakan tinggi apabila nilainya $>2$.

2. Indeks Kemerataan Pielou (Pielou dalam Southwood, 1971)

$E=H / \ln S$

$E$ : Indeks kemerataan Pielou

$\mathrm{H}$ : Indeksi Diversitas Shanon-Wiener

$S$ : Total spesies

Jika :

$0<\mathrm{E} \leq 0,5$ = ada dominansi dalam komunitas, beberapa populasi tertekan;

$0,5<\mathrm{E} \leq 0,75=$ populasi labil;

$0,75<\mathrm{E} \leq 1=$ komunitas stabil (Brower

\& Zar, 1997)

3. Derajat Kemelimpahan

Apabila nilai $E$ berada pada kisaran 0 hingga 0,75 , maka untuk mengetahui spesies apa yang dominan di tiap lokasi dapat diketahui dengan derajat kemelimpahan menurut Kurniati (2003) yaitu sebagai berikut:

a. Melimpah jika terdapat lebih dari 30 perjumpaan/hari

b. Cukup jika terdapat perjumpaan antara 11-30

c. Jarang jika terdapat perjumpaan antara 5 hingga 10

d. Langka jika perjumpaan kurang dari 5 per harinya

\section{Hasil dan Pembahasan}

Nilai indeks keanekaragaman dan kemerataan spesies anggota Ordo Anura di keenam lokasi penelitian di lereng selatan Gunung Merapi dapat dilihat pada Gambar 1.

Lokasi dengan nilai keaneka- ragaman tertinggi kedua adalah Kali Kuning, namun nilai kemerataannya tergolong labil $\left(H^{\prime}=1,25 ; E=0,64\right)$. Terdapat 7 spesies anura di Kali Kuning yaitu Duttaphrynus melanostictus, Fejervarya limnocharis, Huia masonii, Hydrophylax chalconotus, Odorrana hosii, Polypedates leucomystax, dan Rhaco-phorus margaritifer (Gambar 2). Cacah spesies anura yang berada di Kali Kuning adalah yang tertinggi dibandingkan dengan cacah spesies di lokasi lain. Sementara itu, cacah individu per spesies di Kali Kuning tidak seimbang. Masih ada beberapa spesies yang mendominasi di Kali Kuning sehingga ada spesies lain yang jumlah individunya sedikit. Hal tersebut yang membuat nilai kemerataan di Kali Kuning tergolong labil meskipun nilai keanekaragamannya tertinggi kedua dari semua lokasi. 


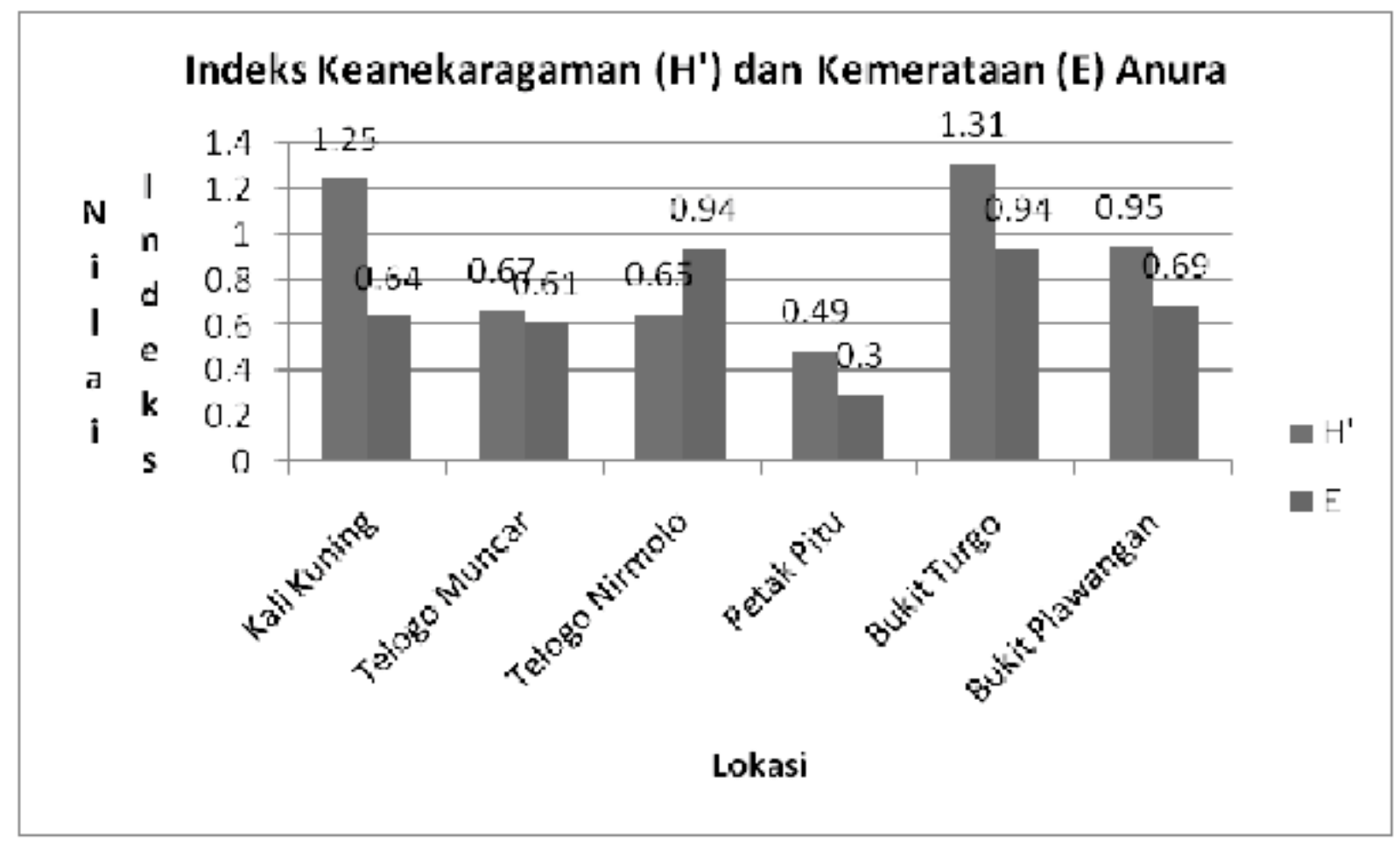

Gambar 1. Indeks Keanekaragaman (H') dan Kemerataan (E) Anura di keenam lokasi

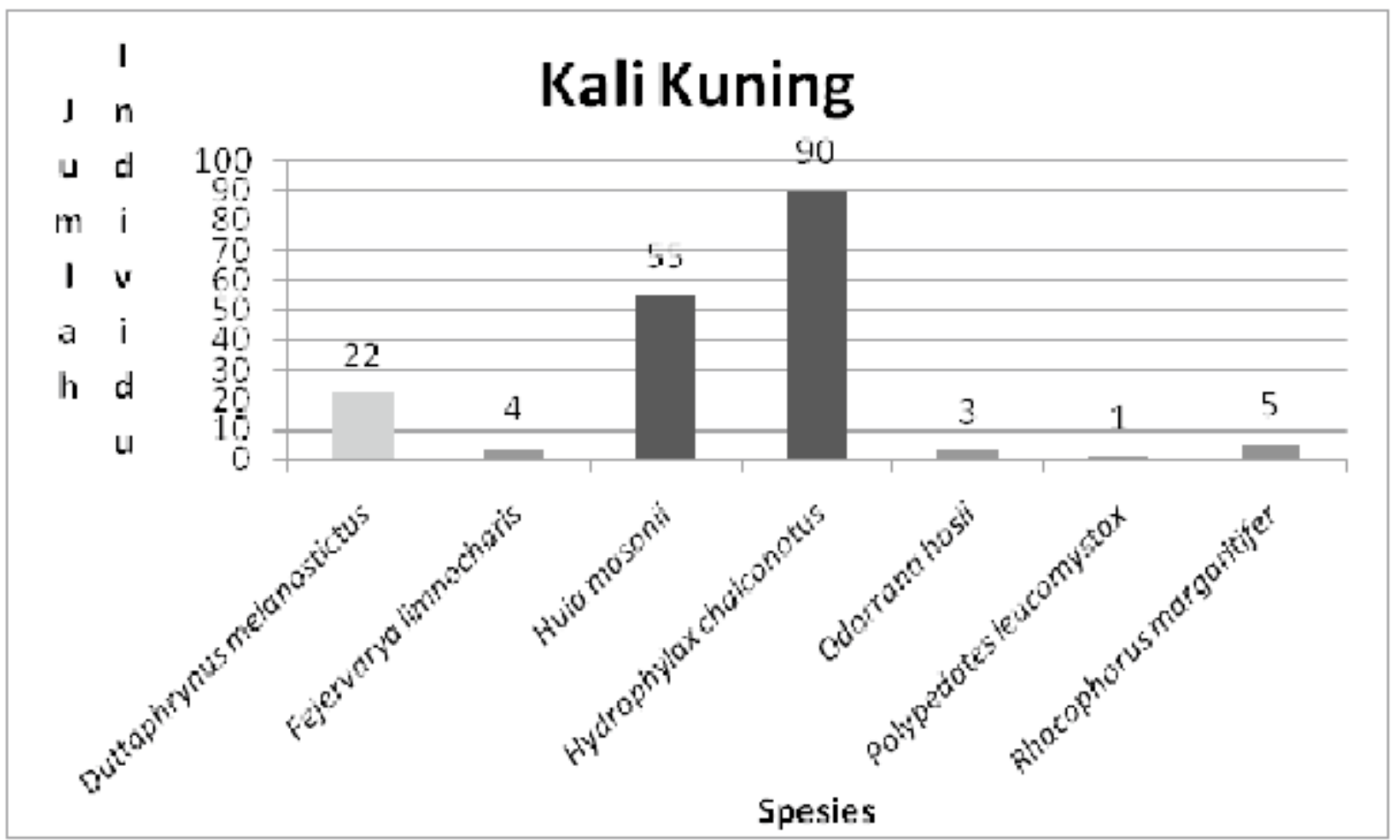

Gambar2. Derajat Kemelimpahan Spesies Anura di Kali Kuning (Merah = melimpah, kuning=cukup, hijau=jarang, biru=langka) 
Dua lokasi lainnya yang memiliki nilai keanekaragaman sangat rendah dan nilai kemerataan yang labil adalah pada Telogo Muncar $\left(H^{\prime}=0,67 ; \quad E=0,61\right)$ dan Bukit Plawangan $\left(H^{\prime}=0,95 ; \quad E=0,69\right)$. Meskipun dapat dikategorikan ke dalam golongan yang sama, namun Bukit Plawangan memiliki nilai keanekargaman dan kemerataan anura yang lebih tinggi daripada Telogo Muncar. Bukit Plawangan memiliki empat spesies anura yaitu Limnonectes microdiscus, Philautus aurifasciatus, Polypedates leucomystax, dan Rhacophorus reinwardtii (lihat Gambar 7). Sementara itu, Telogo Muncar memiliki tiga spesies anura yaitu Hydrophylax chalconotus, Rhacophorus margaritifer, dan Limnonectes kuhlii (Gambar 3).
Berdasarkan cacah spesies memang menunjukkan bahwa Bukit Plawangan memiliki keanekaragaman jenis yang lebih tinggi daripada Telogo Muncar. Sementara itu berdasarkan nilai kemerataan spesies anura juga dapat diasumsikan bahwa persebaran spesies anura di Bukit Plawangan lebih merata daripada di Telogo Muncar meskipun kedua lokasi tersebut masih tergolong ke dalam komunitas yang labil. Nilai kemerataan di kedua lokasi tersebut dapat mengindikasikan bahwa masih ada beberapa spesies anura tertentu yang mendominasi di masing-masing lokasi tersebut. Cacah individu spesies anura yang lain menjadi terganggu akibat dominasi dari spesies tersebut.

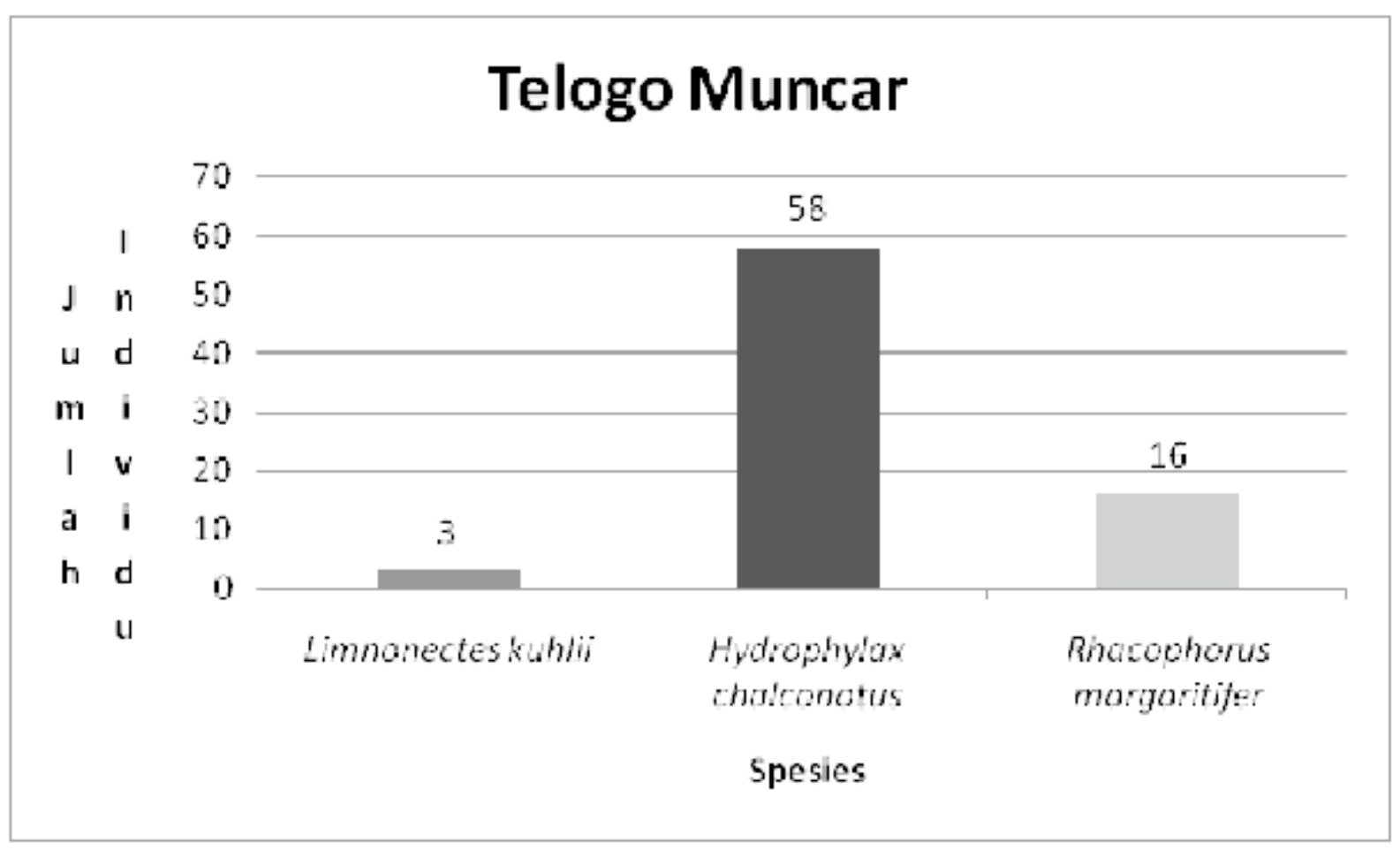

Gambar 3. Derajat Kemelimpahan Spesies Anura di Telogo Muncar (Merah=melimpah, kuning=cukup, hijau=jarang, biru=langka)

Berkebalikan dengan Kali Kuning adalah pada Telogo Nirmolo. Telogo Nirmolo memiliki nilai keanekaragaman yang sangat rendah namun nilai kemerataan spesies anura sudah merata $\left(H^{\prime}=0,65 ; \quad E=0,94\right)$. Hanya ditemukan dua spesies anura di Telogo Nirmolo yaitu Philautus aurifasciatus dan Hydrophylax chalconotus (Gambar 4). Cacah spesies yang rendah tersebut yang menyebabkan nilai keanekaragaman di Telogo Nirmolo tergolong sangat rendah. Meskipun demikian, cacah individu antara kedua spesies tersebut sudah tergolong merata. Tidak ada spesies yang mendominasi atau spesies yang tertekan sehingga komunitas di anura di Telogo Nirmolo sudah dapat dikategorikan stabil. 


\section{Telogo Nirmolo}

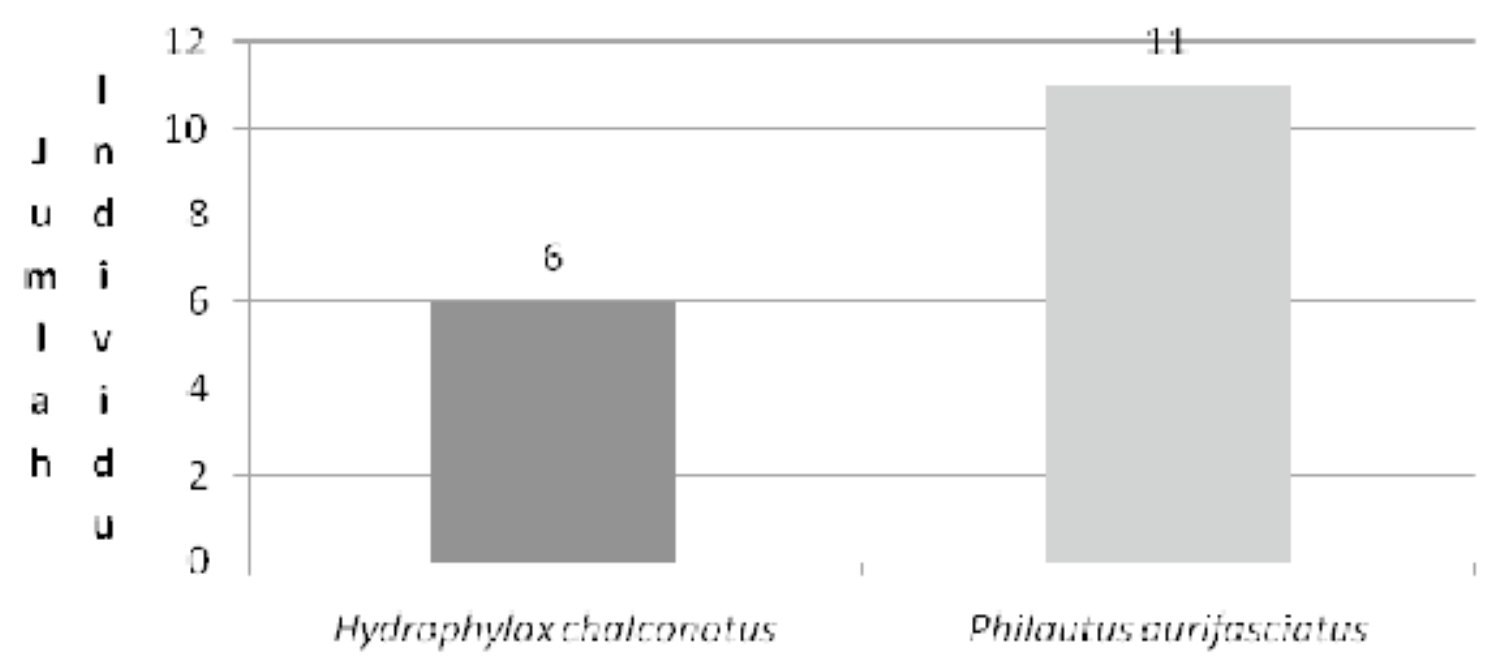

Spesies

Gambar 4. Derajat Kemelimpahan Spesies Anura di Telogo Nirmolo (Merah = melimpah, kuning = cukup, hijau $=$ jarang, biru $=$ langka)

Sementara itu, lokasi dengan nilai keanekaragaman dan kemerataan yang paling rendah adalah pada Petak Pitu $\left(H^{\prime}=0,49 ; \quad E=0,3\right)$. Ditemukan 5 spesies anura di Petak Pitu yaitu Fejervarya limnocharis, Limnonectes microdiscus, Hydrophylax chalconotus, Polypedates leucomystax, dan Leptobrachium hasseltii (Gambar 5). Meskipun cacah spesies yang ditemukan di Petak Pitu lebih banyak daripada di Bukit Turgo, namun nilai keanekaragaman anura di Petak Pitu adalah yang paling rendah. Hal ini dikarenakan cacah individu per spesies anura di Petak Pitu yang tidak seimbang. Hydrophylax chalconotus masih mendominasi di lokasi tersebut sehingga beberapa spesies lain tertekan jumlah individunya. Hal ini dapat didukung dari nilai kemerataan anura di Petak Pitu yang juga menunjukkan nilai 0,3 yang berarti komunitas anura di Petak Pitu masih tertekan. Dominasi yang sangat kuat dari Hydrophylax chalconotus menyebabkan banyak spesies lain yang cacah individunya sangat tertekan. Hal tersebut dapat dipengaruhi oleh ketersediaan pakan alami dan pembagian relung untuk bertelur dimana dominasi dari Hydro- phylax chalconotus menyebabkan bebe- rapa spesies lain kekurangan pakan alami mereka di alam dan tempat untuk bertelur. Selain itu, dapat pula dipengaruhi oleh adaptasi terhadap kualitas sumber air. Air di Petak Pitu sebagian besar sudah mengandung lumpur akibat lahar dingin pascaerupsi Merapi. Hal tersebut menunjukkan bahwa tidak semua spesies anura mampu bertahan di kondisi air yang demikian sehingga hanya spesies-spesies tertentu saja yang mampu beradaptasi dengan kualitas air yang menurun. 


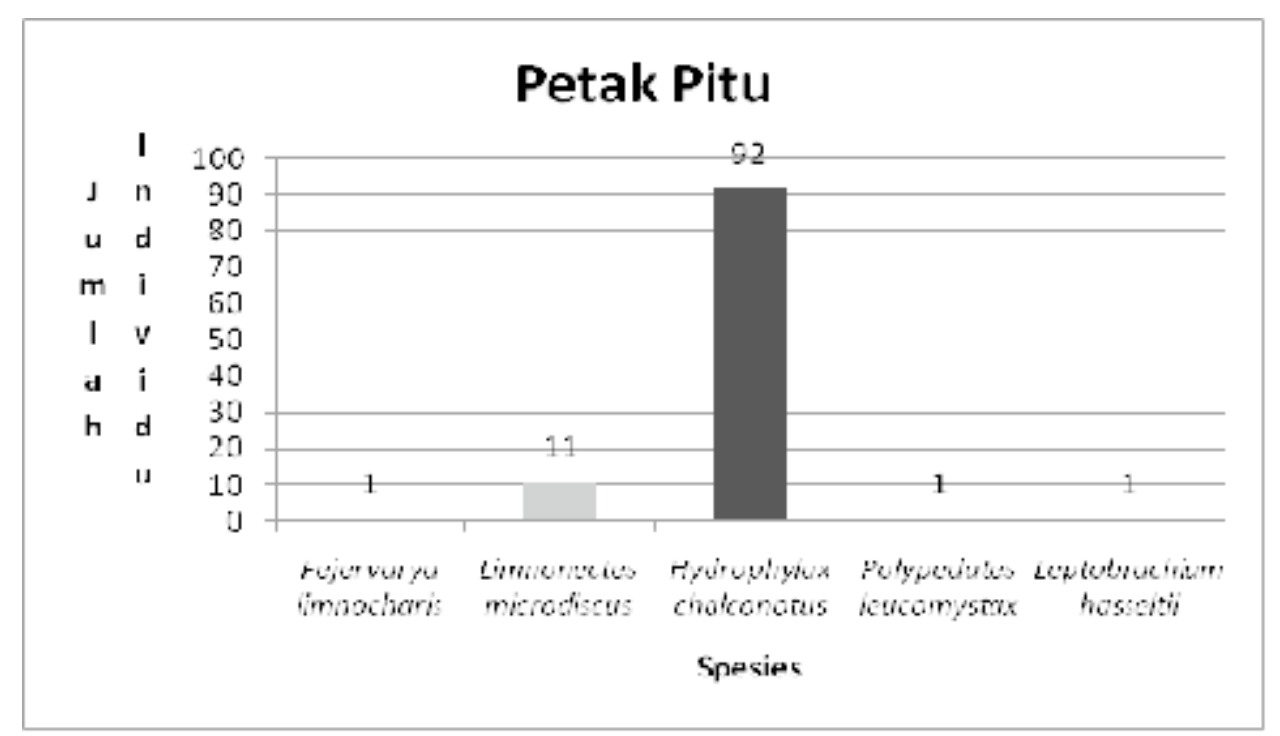

Gambar 5. Derajat Kemelimpahan Spesies Anura di Petak Pitu (Merah= melimpah, kuning=cukup, hijau=jarang, biru=langka)

Lokasi dengan keanekaragaman dan kemerataan tertinggi adalah di Bukit Turgo $\left(H^{\prime}=1,31 ; E=0,94\right)$. Bukit Turgo memiliki cacah spesies sebanyak 4 spesies yaitu Rhacophorus margaritifer, Limnonectes kuhlii, Limnonectes microdiscus, dan Hydrophylax chalconotus (Gambar 6). Nilai keanekaragaman anura di Bukit Turgo tergolong rendah. Meskipun hanya ditemukan empat spesies, keanekaragaman anura di Bukit Turgo adalah yang tertinggi daripada lokasi lainnya. Hal ini dikarenakan cacah individu setiap spesiesnya yang seimbang sehingga tidak ada spesies yang mendominasi. Hal tersebut yang menjadikan keanekaragaman di Bukit Turgo menjadi yang tertinggi. Apabila cacah individu per spesies seimbang, dapat diasumsikan bahwa di lokasi tersebut memiliki potensi keanekaragaman yang tinggi dalam jangka panjang apabila dibandingkan dengan lokasi yang didominasi oleh spesies tertentu. Hal tersebut juga didukung dari nilai kemerataan anura di Bukit Turgo tergolong sudah stabil. Empat spesies anura yang ditemukan di Bukit Turgo memiliki cacah individu per spesies yang merata sehingga nilai kemerataannya tinggi dan dapat dikategorikan stabil. Dapat diasumsikan bahwa pada Bukit Turgo, tidak ada spesies anura yang mendominasi atau tertekan jumlahnya.

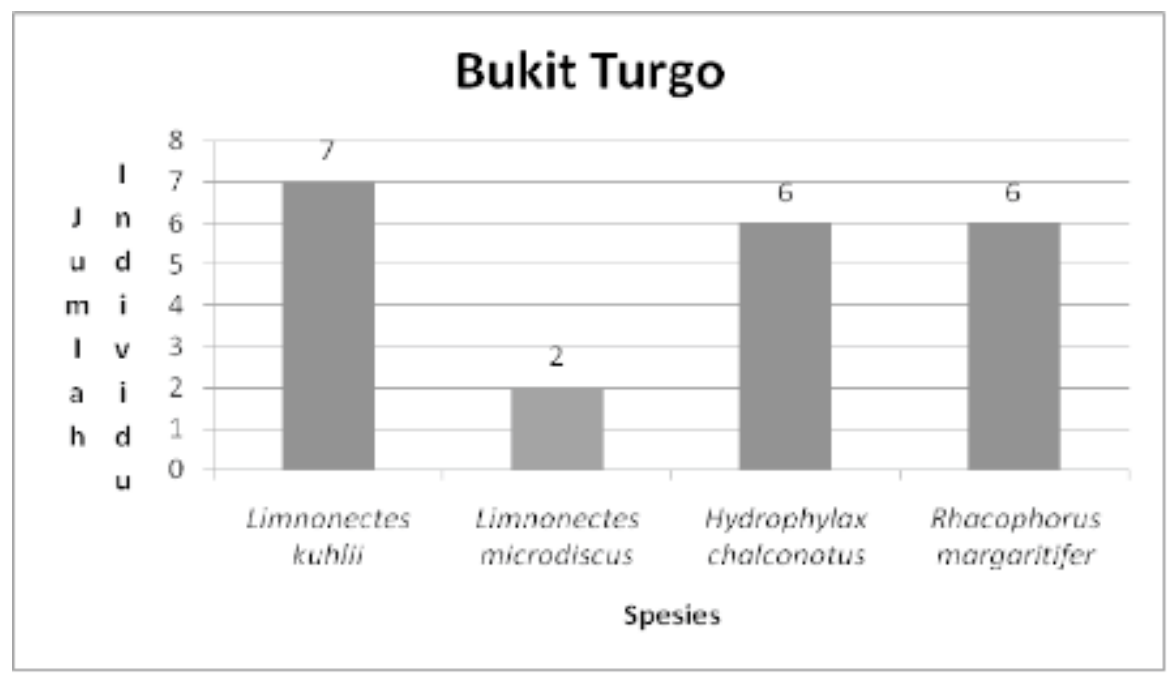

Gambar 6. Derajat Kemelimpahan Spesies Anura di Bukit Turgo (Merah = melimpah, kuning = cukup, hijau = jarang, biru = langka) 


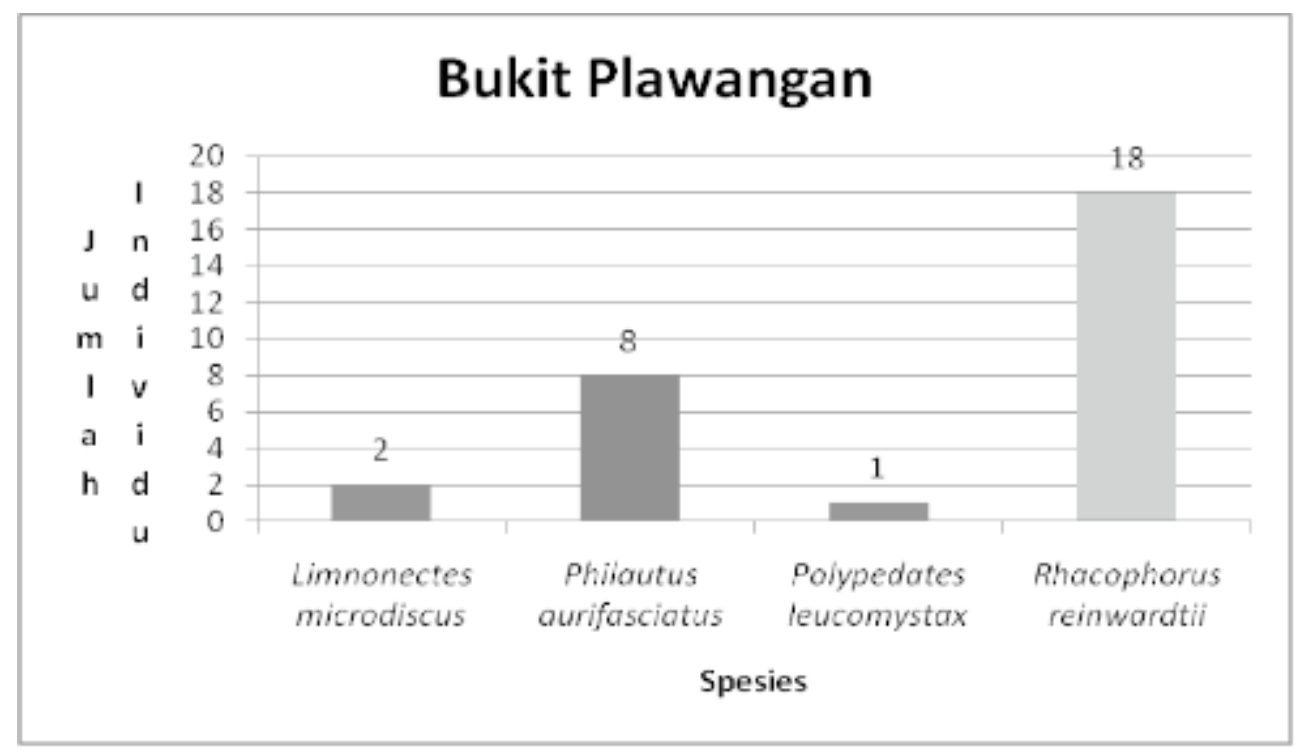

Gambar 7. Derajat Kemelimpahan Spesies Anura di Bukit Plawangan (Merah= melimpah, kuning=cukup, hijau=jarang, biru=langka)

\section{Simpulan}

Keanekaragaman jenis anggota Ordo Anura di lereng selatan Gunung Merapi ada 12 jenis yang tersebar di 6 lokasi. Jenis-jenis yang ditemukan adalah Limnonectes microdiscus, Philautus aurifasciatus, Polypedates leucomystax, Rhacophorus reinwardtii, Limnonectes kuhlii, Hydrophylax chalconotus, Rhacophorus margaritifer, Fejervarya limnocharis, Leptobrachium hasseltii, Duttaphrynus melanostictus, Huia masonii, dan Odorrana hosii.

Lokasi dengan nilai keanekaragaman dan kemerataan yang tertinggi dan terendah secara berturut-turut adalah Bukit Turgo $\left(H^{\prime}=1,31 ; E=0,94\right)$ dan Petak Pitu $\left(H^{\prime}=0,49\right.$; $E=0,3)$. Kali Kuning adalah lokasi dengan nlai keanekaragaman yang tertinggi kedua (tergolong rendah) namun nilai kemerataannya tergolong labil $\left(H^{\prime}=1,25\right.$; $E=0,64)$. Telogo Nirmolo memiliki nilai keanekaragaman yang sangat rendah namun nilai kemerataannya sudah tergolong stabil $\left(H^{\prime}=0,65 ; E=0,94\right)$. Lokasi dengan nilai keanekaragaman yang sangat rendah dengan nilai kemerataan yang tergolong labil adalah Telogo Muncar $\left(\mathrm{H}^{\prime}=0,67\right.$; $E=0,61)$ dan Bukit Plawangan $\left(H^{\prime}=0,95\right.$; $E=0,69$ ).

\section{Saran}

Penelitian ini adalah penelitian yang dilakukan di musim kering atau musim kemarau. Diharapkan ada penelitian serupa mengenai keanekaragaman dan kemerataan spesies anggota Ordo Anura di lereng selatan Gunung Merapi yang dilakukan di musim hujan. Data yang didapat dapat saling melengkapi untuk melihat pola keanekaragaman dan kemerataan anura dalam satu tahun atau dua musim. Data tersebut juga dapat digunakan untuk m e mbandingkan perbeda $n$ keanekaragaman dan kemerataan anura di dua musim yang berbeda.

\section{Ucapan terima kasih}

Diucapkan terima kasih kepada penyedia dan pengelola Hibah Penelitian Mahasiswa Dana Masyarakat Fakultas Biologi Universitas Gadjah Mada Tahun Anggaran 2012 (TP3F) yang telah mendanai kegiatan penelitian ini. Ucapan terima kasih juga diucapkan kepada Balai Taman Nasional Gunung Merapi (TNGM) yang telah memberikan izin untuk melakukan penelitian di lokasi TNGM. Serta untuk Kukuh Indra Kusuma, S.Si, Tony Febri Qurniawan, S.Si, Hastin Ambar Asti, S.Si atas diskusi yang bermanfaat, dan rekan-rekan Kelompok Studi Herpetologi (KSH) Fakultas Biologi UGM atas bantuan dukungan serta tenaga saat melakukan sampling di lapangan. 


\section{Daftar Pustaka}

Andayani, T.T. 2011. Dana Sumbangan masyarakat Untuk Pembangunan Ekonomi Pasca Bencana Merapi. Jurnal Penanggulangan Bencana. 2(1): 41-49

Brower, J.E., J.H. Zarr. 1997. Field and Laboratory for General Ecology. W.M.C Brown Company Publishing, Portugue, lowa.

Eprilurahman, R. dan K.I. Kusuma. 2011. Amfibi dan Reptil di lereng selatan gunung api Merapi sebelum erupsi 2010. Berkala IImiah Biologi 10(1):18.

Heyer, W.R., M.A. Donnelly, R.W. McDiarmid, L.C. Hayek and M.S. Foster. 1994. Measuring and Monitoring Biological Diversity: Standard Methods for Amphibians. Smithsonian Institution Press, United States of America.

Howell, K. 2002. Amphibians and reptiles: the reptiles. In: Davies G, Hoffman M (eds). African forest biodiversity: a field survey manual for vertebrates. Earthwatch Institute. London.
Iskandar, D.T., 1998.Amfibi Jawa dan Bali: Seri Panduan Lapangan, Cetakan pertama, Puslitbang Biologi-LIPI. Bogor.

Iskandar, D. T., E. Colijn. 2001. Checklist of Southeast Asian Herpetofauna I. Amphibians. Treubia 31(3) : 1-133.

Kurniati, H. 2003. Amphibian \& Reptiles of Gunung Halimun National Park West Java, Indonesia (Frog, Lizard and Snakes): An Illustrated Guide Book. Research Center for Biology (LIPI) and Nagao Natural Environment Foundation (NEF). Cibinong.

Kusrini, M.D. 2009. Pedoman Penelitian dan Survei Amfibi di Alam. Pustaka Media Konservasi - Fakultas Kehtanan IPB. Bogor.

Odum, H.T. 1971. Environment, Power, and Society. Wiley Interscience. New York.

Southwood, T.R.E. 1971. Ecological methods. Chapman and Hall. London 